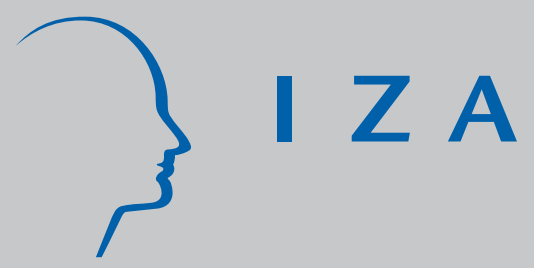

IZA DP No. 258

The Times They are A-Changin'

Organizational Change and Immigrant Employment

Opportunities in Scandinavia

Michael Rosholm

Kirk Scott

Leif Husted

February 2001 


\title{
The Times They Are A-Changin' Organizational Change and Immigrant Employment Opportunities in Scandinavia
}

\author{
Michael Rosholm \\ Department of Economics, Aarhus School of Business, CIM, CLS and IZA, Bonn \\ Kirk Scott \\ Department of Economic History, University of Lund \\ Leif Husted \\ Institute of Local Government Studies and CIM
}

Discussion Paper No. 258

February 2001

\author{
IZA \\ P.O. Box 7240 \\ D-53072 Bonn \\ Germany \\ Tel.: +49-228-3894-0 \\ Fax: +49-228-3894-210 \\ Email: iza@iza.org
}

This Discussion Paper is issued within the framework of IZA's research area Mobility and Flexibility of Labor Markets. Any opinions expressed here are those of the author(s) and not those of the institute. Research disseminated by IZA may include views on policy, but the institute itself takes no institutional policy positions.

The Institute for the Study of Labor (IZA) in Bonn is a local and virtual international research center and a place of communication between science, politics and business. IZA is an independent, nonprofit limited liability company (Gesellschaft mit beschränkter Haftung) supported by the Deutsche Post AG. The center is associated with the University of Bonn and offers a stimulating research environment through its research networks, research support, and visitors and doctoral programs. IZA engages in (i) original and internationally competitive research in all fields of labor economics, (ii) development of policy concepts, and (iii) dissemination of research results and concepts to the interested public. The current research program deals with (1) mobility and flexibility of labor markets, (2) internationalization of labor markets and European integration, (3) the welfare state and labor markets, (4) labor markets in transition, (5) the future of work, (6) project evaluation and (7) general labor economics.

IZA Discussion Papers often represent preliminary work and are circulated to encourage discussion. Citation of such a paper should account for its provisional character. 
IZA Discussion Paper No. 258

February 2001

\section{ABSTRACT \\ The Times They Are A-Changin' \\ Organizational Change and Immigrant Employment Opportunities in Scandinavia*}

This article compares and contrasts male immigrant labor market experiences in Sweden and Denmark during the period 1985 - 1995. Using register-based panel data sets from Sweden and Denmark, a picture of the employment assimilation process of immigrants from Norway, Poland, Turkey, and Iran is brought forth. The comparative approach shows that immigrants in Sweden and Denmark experienced similar declines in employment prospects between 1985 and 1995 despite quite different developments of aggregate labor market conditions. The explanation offered here is that the changing organizational structure - towards more flexible work organization - has resulted in a decrease in the attractiveness of immigrant employees due to the increasing importance of country-specific skills and informal human capital.

JEL Classification: J61, J71, L23, O30

Keywords: Immigrants, employment assimilation, organizational change

Michael Rosholm

Department of Economics

Aarhus School of Business

Fuglesangs Alle 20

8210 Århus V

Denmark

Tel.: +4589421559

Fax: +45861363 34

Email: mrosholm@econ.au.dk

\footnotetext{
* This paper is written within the research project "Labour Demand, Education and the Dynamics of Social Exclusion" funded by European Commission under the TSER network (contract number SOE2-CT973052), the Swedish Council for Research in Humanities and Social Science, and the Danish Social Research Council (FREJA and the program "Polarization of The Welfare Society and The Funding Crisis").
} 


\section{Introduction}

This article charts the change in the employment assimilation process of first generation male immigrants from selected countries in Denmark and Sweden during the period 1985 - 1995. A comparative analysis of employment performance gives evidence of a significant negative impact of organizational change on the employment opportunities of immigrants.

Denmark and Sweden are both Scandinavian countries with well-developed social welfare systems, and similar cultural and historical backgrounds. Despite these extensive similarities, there are a number of differences in national labor market experiences, which will allow for a better understanding of the processes underlying immigrant economic integration.

One aspect in which Sweden and Denmark have had varying experiences is unemployment rates. As seen in figure 1, both Sweden and Denmark enjoyed quite

Figure 1 Unemployment in Denmark and Sweden, 1960 - 1999. Percent.

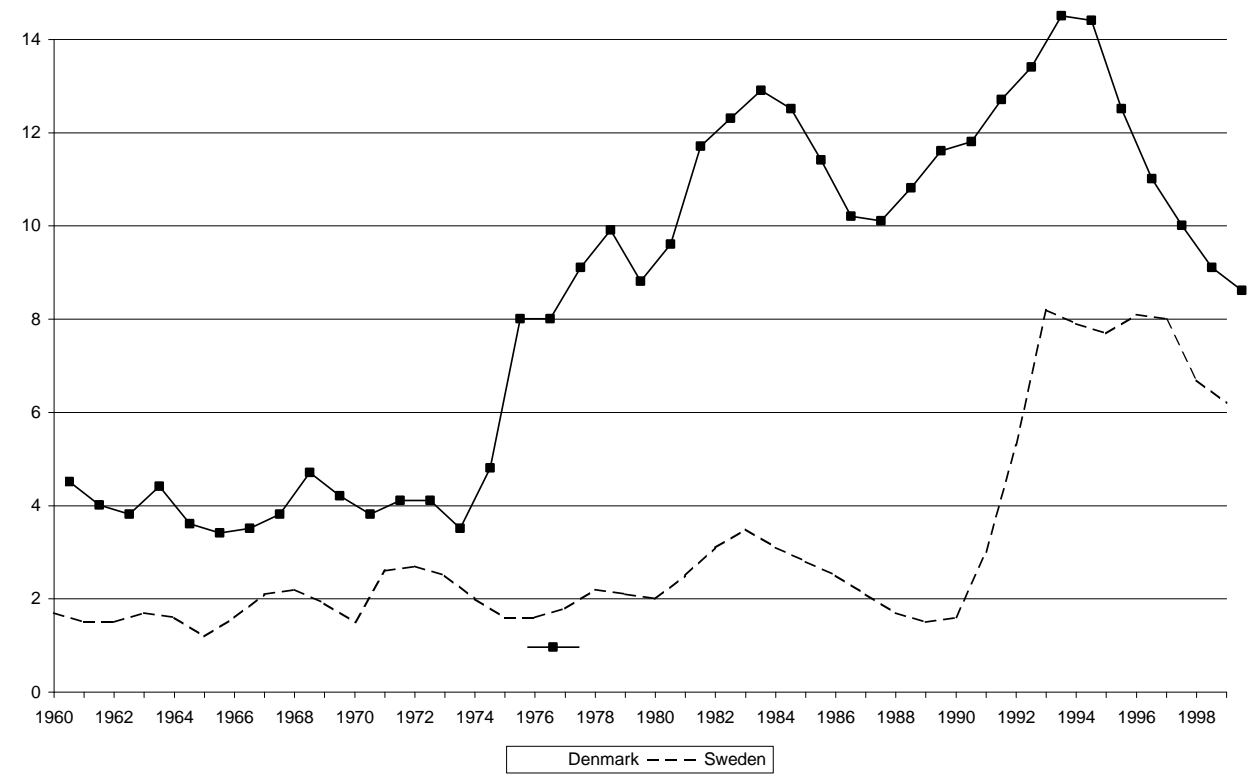

low unemployment during the 1960s. This decade saw unemployment levels of less than two percent on average for both countries, but this situation was to change dramatically in the following period. Sweden maintained relatively low unemployment rates for the 1970s and throughout the 1980s, while Denmark diverged to take on unemployment levels of a more European character. 
Figure 1 clearly shows that the economic situations in Denmark and Sweden were quite different during the 1980s, despite similar political, social and economic institutions. By the early 1990s, however, the unemployment rates had 'converged'. This development provides us with an opportunity to examine the effects of cyclical and structural developments on immigrant economic performance.

A look at annual GNP growth (not presented here) shows that there existed no serious differences in growth rates between Sweden and Denmark during the entire period from 1960 through 1999, although the two countries did not share the same cyclical patterns. A look at the period of interest to this study does show some difference, however, with Denmark having lower growth rates in the late 1980s, followed by increasing rates in the early 1990s, while Sweden experienced stagnant or even negative GNP growth during the first years of the 1990s. It is first in the mid 1990s that Sweden's growth rate returns to Danish levels.

Given the above situation, it can be said that the period 1985 - 1995 began with Sweden and Denmark experiencing quite different economic conditions, and ended with the two nations exhibiting similar levels of unemployment and economic growth. Therefore, ceteris paribus, the employment prospects of immigrants in these two countries should differ in the early period, and then become increasingly similar as time goes by.

This would be the case if the economic performance of immigrants was purely a function of the macroeconomic climate in the destination country. This is not believed to be the actual case, however. ${ }^{1}$ Evidence from Sweden points to weakening immigrant labor market attachment and income performance even during the cyclical upturn of the late 1980s (Scott 1995, 1999; Bevelander 1998; Bevelander and Nielsen 1999), pointing to a deterioration in labor market assimilation of a non-cyclical nature. This article will show that the labor market performance of immigrants deteriorated in both Denmark and Sweden during the late 1980s and early 1990s, even after correcting for individual effects, cohort effects, and cyclical effects. Furthermore, this deterioration is shown to increase with the 'cultural distance' from the immigrants' origin country to Denmark/Sweden. This is taken as evidence that organizational changes in the labor

\footnotetext{
1 A look at the raw employment rates of immigrants relative to natives is not very informative on this issue, since the composition of immigrants change, and in addition the immigrants residing in Denmark and Sweden in 1995 have on average been in the countries for a longer period - see the descriptive statistics in the appendix.
} 
market away from assembly line production work towards multi-tasking, teamwork, the use of computers etc. (see Snower 1999), do not benefit immigrants, as their informal - 'linguistic and cultural' - capital, which is becoming increasingly important, is not sufficient to obtain and keep jobs. Specifically, we present evidence that suggests that the deterioration in employment opportunities is caused by increasing statistical discrimination performed by employers on certain groups of immigrants.

The analysis is performed by using similar data sets - drawn from administrative registers - of immigrants to Denmark and Sweden and 'control samples' of Danes and Swedes to analyze immigrants' employment relative to natives. The methodology used is a panel-data probit model, which is designed to correct for individual-specific effects.

\section{Previous Research}

Earlier studies on differences in native-immigrant employment rates and relative incomes of immigrants have shown a varied picture. Accounting for 10 and 5 percent of the populations in Sweden and Denmark, respectively, nearly all groups of immigrants in Sweden and Denmark have lower employment rates than natives. Almost identical patterns are found in other Western European countries with similar labor market conditions, e.g. Germany, the Netherlands and England (Schmidt 1994; Penninx, Schoorl, and van Praag 1993; Kee 1994; Shields and Price 1996).

North American studies, on the other hand, find for Canada that immigrants assimilate quickly (Baker and Benjamin 1996) and for the USA that immigrants have a lower employment rate and a higher unemployment rate than the native born during the first years in the US, and they then catch up to reach a stable employment and unemployment rate (Chiswick and Hurst 1996; Chiswick, Cohen and Zach 1997). Much recent research points towards nationality and time of entry as significant factors in the labor market assimilation of immigrants (Borjas 1985, 1987, 1989, 1994, 1995; Fry 1997). Here we see discussion of the importance of motivation, scarring effects of time at entry, and other, non-observable characteristics. Other studies point to increased investments in language leading to higher earnings and greater chances of finding employment (McManus 1985; Chiswick and Miller 1995, 1999; Dustmann 1994, 1999). 
In the Swedish case, studies on the economic integration of immigrants show a very high labor market attachment during the 1950s and 1960s with high employment rates and relatively high incomes (Wadensjö 1973; Ohlsson 1975; Ekberg 1983). Current research into the situation of the 1970s and 1980s shows a different picture, characterized by low immigrant employment rates and relatively low incomes. Not even the economic upturn in the late eighties served to reverse the development. In fact, the opposite happened as incomes and employment rates of immigrants decreased, even for immigrant groups that had been in Sweden for more than twenty years (Ekberg 1990, 1991; Bevelander 1995, 1998; Bevelander and Nielsen 1999; Scott 1995, 1999). These studies suggest that not only supply side factors, but also demand side and institutional factors work to explain the poor labor market attachment of immigrants. It is argued that there has been a shift towards increasing discrimination by authorities, employers, and employees (Broomé, Bäcklund, Lundh and Ohlsson 1996). At the institutional level, the policies pertaining to immigration, integration and the labor market have influenced the labor market success of immigrants both on entry and in the long run (Bevelander, Carlsson and Rojas 1997; Kamali 1997; Blos, Fischer and Straubhaar 1997).

There is not much empirical work on the integration of immigrants in Denmark. In Hummelgaard et al (1995), the labor market performance of immigrants from less developed countries is compared with the performance of Danes. They find that unemployment is much more common among immigrants and that, once unemployed, immigrants stay unemployed longer. They also find that there are large differences in the integration of immigrants from different regions of the world. The same is found in Husted et al (2000a), where wage and employment assimilation profiles are estimated for the time period 1984 to 1995. They find no strong evidence of employment assimilation for immigrants in the Danish labor market, but they find at least a declining employment gap during the first 10 years after immigration. 


\section{Foundation and Hypotheses}

This article presents the hypothesis that the changing organizational structure of modern industrialized economies has adversely affected immigrants. The explosion in computerization, which began during the late 1970s and early 1980s, has altered traditional production methods as well as opened the door for new spheres of economic activity. The traditional, hierarchical industrial organization is no longer necessary, and can even be seen as a disadvantage. Snower (1999) argues that

“... many of the inherited methods of producing, working, and managing - based on the insights gained from more than a century of division of labor, standardization, and mass production - are now widely obsolete."

Computerization has brought with it the ability to control entire production processes with a minimum of workers. The reporting route from lowest assembly-line worker to uppermanagement is often much more direct today than it was in the 1960s, and the demands on workers are subsequently much greater. ${ }^{2}$

While this change may be beneficial to the economy in general, and for certain groups of workers in particular, it is hypothesized that the effects should be negative on members of the workforce not raised in the country. Language skills for immigrants were not of vital importance in the traditional industrial economy. Those employed in manufacturing were often at lower levels, and performed relatively monotonic work with little interaction among coworkers. Today's organizational structure often involves concepts such as job rotation, quality circles, and work teams, all of which increase the need for interpersonal communication, and therefore implicitly favor natives.

This perspective can be seen as an expansion of the view of technological change and capitalskill complementarity. ${ }^{3}$ The traditional view here is that increased technology often leads to increased demands for educated labor, and widens the wage gap between the educated and the uneducated. Here we also assert that it increases the demand for those "educated" in the

\footnotetext{
2 For a thorough discussion of this process, and the changes in work organization in general, see Snower (1999).

${ }^{3}$ See Goldin \& Katz (1996).
} 
functioning of the local society and the labor market. Thus, even highly educated immigrants may suddenly find themselves in the same category as the uneducated natives.

Given the perspective of organizational change, and the hypothesis that it strikes disproportionately at immigrants, what is to be expected in a real world examination of data? The purpose of this work is to examine the possible validity of this perspective using empirical data from Denmark and Sweden.

Empirical evidence suggests that the process of organizational changes is particularly widespread in Denmark and Sweden (OECD, 1999), especially in dimensions such as job rotation, team-based work organization, greater involvement of lower level employees, and the flattening of management structures. Hence, Danish and Swedish data sets on immigrants and natives are ideal for investigating the issues described above.

If there is indeed a structural effect, which affects immigrants disproportionately, then we should expect to find several indicators in the empirical data. The first should be that - given our hypothesis that the organizational changes work against immigrant assimilation - as the changes become more extensive and spread throughout the economy, the problems should become evident through lower immigrant employment rates. In addition, these problems should be worse for immigrants from nations which can be classified as more "culturally distant."

A second indicator should be in the effect of the business cycle. The changes evident in immigrant economic performance should be occurring independently of the business cycle. In a world where immigrants and natives are interchangeable, the business cycle should account for most of the shifting economic prospects of both groups. In our framework, however, the two are no longer interchangeable due to increased emphasis on skills that give natives an advantage. This hypothesis can be tested using the comparative approach in this paper. If the organizational change towards newer organizational forms occurred simultaneously in Sweden and Denmark, which is assumed ${ }^{4}$, then we should see similar movements in employment assimilation among immigrants in Denmark and Sweden. The fact that the two countries have differing unemployment levels and business cycles which are not entirely in sync should lead to different assimilation trends in the two countries if the structural component is of little importance. 
In short, if the development of immigrants' employment performance in Denmark and Sweden is similar over time, we will attribute this to the impact of organizational change, while different developments in the two countries may be attributed to cyclical effects. The next question is how to test this. One method is to introduce time dummies that will measure any changes in the levels of employment. It may be that organizational change, however, affects not only the level, but also the shape of assimilation profiles (the relation between e.g. employment level and years since migration). The argument here is that if there is an increasing need for 'linguistic and cultural' capital, then employers are likely to perform statistical discrimination on any groups that are perceived to have less of these factors on average. Thus, according to this line of argument, statistical discrimination will be based on the country of origin (in actual practice based on your name) rather than on human capital factors. ${ }^{5}$ As such, the variable 'Years Since Migration' (YSM) should become less important in the employment equation as the process of organizational change intensifies. To test for this effect we will allow the parameters determining the shape of the assimilation profiles to change over time.

\section{Data}

The Swedish and Danish data used in the analysis come from public registers maintained by Statistics Sweden and Statistics Denmark, respectively. The Swedish data set is a stratified sample of immigrants (from 16 major origin countries) and Swedes, followed from 1968 through 1996. Some of the information used in this study is only available from 1985, however. The data is described in more detail in Scott (1999). The Danish data set consists of the entire immigrant population in Denmark and their children, followed during the period 1984 through 1995. In addition, we have a data set containing $10 \%$ of all Danes in the age group 16-75. The Danish data sets are described in some detail in Husted et al. (2000a).

\footnotetext{
${ }^{4}$ For more empirical evidence of the prevalence of flexible working structures in Sweden and Denmark, see OECD (1999).

${ }^{5}$ It is by now a stylized fact in the Nordic countries that employers select among job applicants by removing first all those with a 'strange' - from a Nordic point of view - name. This has been documented through several 'experiments' where immigrants 'faking' a Danish name suddenly are invited for job interviews where they were previously rejected.
} 
In order to make our data as comparable as possible (and to facilitate the empirical analysis), a sub-sample of first generation immigrants to Denmark and Sweden from 4 major immigrant countries is extracted, such that there are approximately 2,500 individuals from each of the origin countries. The countries are Norway, Poland, Turkey, and Iran, with the order in which these countries are mentioned reflecting assumed cultural proximity to Denmark and Sweden. In addition, samples of approximately the same size of Danes and Swedes are selected.

The sample is subsequently restricted to include only males 6 in the age group 20-59 years, who are not currently in education, and who are not currently self employed. Both panels are then censored, so that they cover the period 1985 through 1995. In this period, a number of variables are available that are defined in a similar fashion in the two countries.

The dependent variable, an annual employment indicator, takes the value one if the individual has been working during the year. To be classified as 'working during the year' an individual must have positive reported earnings. This is, admittedly, a very generous measure of employment. However, as can be seen from Figure A1 in the appendix, employment rates of immigrants are still very low. We have experimented with other definitions of employment, but the results presented below are robust to such changes.

We note from Figure A1, that native Danes and Swedes experience weakly falling employment rates over the period. In Denmark, employment rates of Norwegians and Poles were fairly constant, whereas those of Turks fell, while employment rates for Iranians increased, albeit from a very low initial level. It should be noted, however, that Iranians in 1985 had only been in Denmark for 2 years on average, while in 1995 this average had increased to 8.4 years (see Table A1 in the appendix). In Sweden, employment rates were fairly constant until 1990, when they began to fall for all groups, but most notably for immigrants from Turkey and Iran - the culturally and linguistically most distant of the immigrants groups. Not much can be said about the impact of organizational change from Figure A1, however. To do this, an econometric modeling strategy is necessary, and the econometric model is described in the next section.

\footnotetext{
6 The behaviour of immigrant females from less developed countries with respect to the labor market is so different - and difficult to explain - that they are removed here to maintain the focus of the paper. For a discussion of these issues for Denmark, see Husted et al. (2000b).
} 
The human capital variables include age at migration (AAM) and its square, and years since migration (YSM) and its square. For the education variable a set of indicators measuring level of education obtained in Sweden/Denmark are used, with no education as the reference category, and then educational level is divided into five groups: primary, secondary, and theoretical 1, 2, and 3. The theoretical categories correspond roughly to two-year university, bachelor's degree and graduate degree. ${ }^{7}$ The effect of marital status is captured by an indicator variable taking the value 1 for married individuals and 0 otherwise, ${ }^{8}$ and finally, the number of children is used. We also use an indicator measuring if an immigrant has become naturalized that is, whether he has received Danish or Swedish citizenship.

Demand factors include geographical information, grouped into metropolitan area (ref.), and non-metropolitan area. To measure time-specific effects, we include a set of annual dummies.

In addition to the time dummies, a trend effect on YSM for immigrants and on Age for natives is also included, to capture changing effects expected for experience as time progresses.

We estimate separate equations for each origin country. Additional important information such as pre-immigration education, working experience etc. is unfortunately not available. This problem is reduced by the fact that we employ a random effects estimator.

Descriptive statistics for Danish and Swedish immigrants as well as for the aggregate variables are reported in Tables A1 and A2 in the Appendix.

\footnotetext{
${ }^{7}$ The education obtained in the home country is not available for immigrants in Denmark, hence - although it is available for Swedish immigrants - we have not included this information.

${ }^{8}$ For Denmark, this variable measures cohabitation as well as marriage.
} 


\section{Econometric Specification}

We will be performing an analysis of the determinants of employment probabilities, and we would like to exploit the panel structure of our data sets, so as to avoid cohort immigration effects (Borjas 1987) among other things. The appropriate type of estimator is thus a binary choice panel data estimator. Framing the model in a latent utility framework, let the utility of working for individual $i$ at time $t$ be denoted by $y_{i t}$. This index may depend on a number of explanatory variables in the following manner

$$
y_{i t}=Y S M_{i t} \beta+x_{i t}^{\prime} \gamma+\delta_{t}+\alpha_{i}+\varepsilon_{i t}
$$

where YSM denotes years since migration (we have ignored squared terms for the ease of exposition) and $x$ is a vector of other individual characteristics. Now, in our case, we would like to analyze if the employment assimilation profiles flatten over time, that is, whether the parameter $\beta$ changes over time. The most flexible way to do this is to introduce period-specific $\beta$ 's. This approach showed a linear trend in the parameters, which lead us to estimate the restricted model

$$
y_{i t}=Y S M_{i t} \cdot\left[\beta_{0}+\beta_{1}(t-1985)\right]+x_{i t}^{\prime} \gamma+\delta_{t}+\alpha_{i}+\varepsilon_{i t}
$$

in order to gain efficiency. We were able to reject the hypothesis that the more general model was better, and hence, we report the estimates from this restricted equation. The linear trend is allowed in the parameters on YSM and its square. The dependent variable in the study is thus an indicator taking the value 1 if the individual $i$ has worked in the year $t$ (that is, if $y_{i t}>0$ ) and 0 otherwise.

We have chosen to estimate a random effects probit model. The $\delta_{t}$ are time effects, which capture level shifts in employment probabilities over time. The $\alpha_{i}$ are random individual- 
specific effects, which are are assumed to follow a discrete distribution with two points of support. ${ }^{9}$

\section{Results}

In this section we present the results from the estimation of separate employment equations for native men and men from the selected four immigrant countries, in Denmark and Sweden. The complete regression results are presented in the appendix, and here we present only graphical interpretations of immigrant assimilation profiles. The calculation of these profiles is based upon a typical individual with given characteristics, with the only difference being nationality. The individual is defined as a male, aged 26 upon entry into Denmark / Sweden, living outside of a metropolitan area, married or cohabiting, with one child, and primary school education obtained in Denmark / Sweden. Note that a different choice of standard person may change the relative positions of the employment assimilation profiles, but the evolution of the profiles from 1985 to 1995 will be (approximately) the same irrespective of this choice. The profiles show the progression in the employment probability with increased years since migration, or increased age in the case of natives.

The benefit of this approach is that it allows an easy overview of the comparative performance of individuals who differ only in terms of their ethnic/national backgrounds. The diagrams were constructed using the values of the relevant parameters in 1985 and 1995 in order to identify differences between the beginning and the end of our study. ${ }^{10}$ The traditional problems associated with construction of lifetime profiles based upon single years are avoided through the use of a panel data estimation methodology, and by the stratification into samples for different origin countries.

Figure 2 shows employment development for immigrants and natives in Denmark in 1985 and 1995. For native Danes, employment rates are very high in both years, and they show a slight decline with increasing age (for natives, YSM=1 corresponds to an individual aged 26).

\footnotetext{
9 We have experimented with several econometric specifications, such as a logit model, a normal mixing distribution, more than two points of support etc., but the estimation results were robust to such changes.

10 The parameters differ over time due to the interaction of YSM with a time trend, and due to the presence of time dummies. For natives, Age is interacted with a time trend.
} 
Figure 2 Employment development with years since migration, Denmark

\section{Denmark 1985}

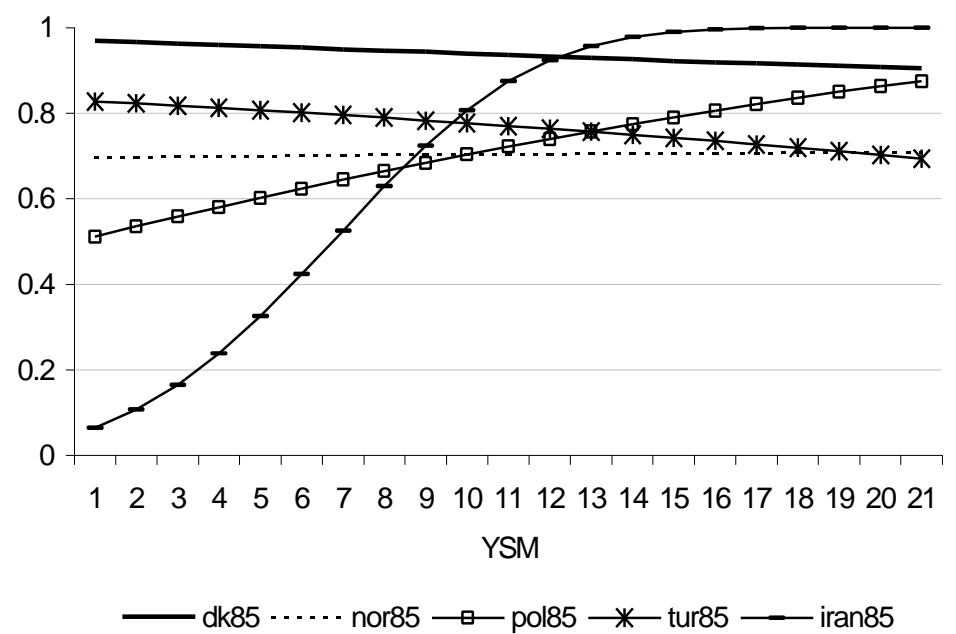

Denmark 1995

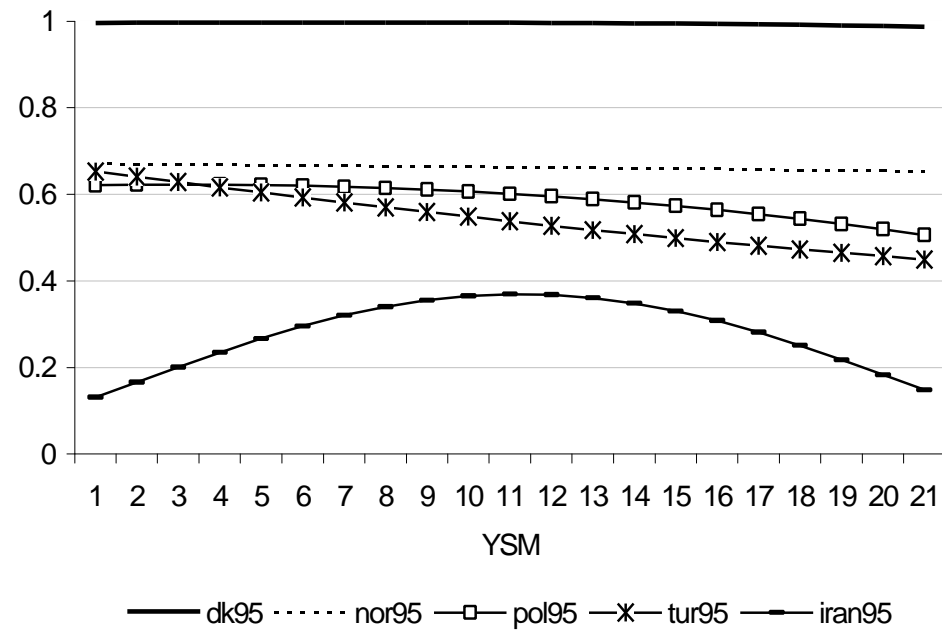

For Norwegian immigrants, employment rates have also been fairly constant, falling from slightly above $70 \%$ to slightly below, but for non-Nordic immigrants there has occurred a dramatic change in calculated employment probabilities. The profiles for all non-Nordic immigrants displayed 'better' patterns in 1985 compared to 1995. By 1995 the assimilation patterns had either shifted downwards or, in the case of Poland, shifted from upward to downward sloping. This indicates that the positive effects of years since migration from the 1985 data was less pronounced or even absent in 1995. Norwegian immigrants do not seem to 
have experienced any changes in relative employment probabilities during the period under investigation.

Figure 3 portrays a similar situation for Sweden, with certain differences. While the Danish case showed a shifting of in some cases already negatively sloping profiles, the Swedish profiles were generally more positive in 1985 than the Danish ones, with noticeable improvement with increased years in the country.

Figure 3 Employment development with years since migration, Sweden

\section{Sweden 1985}

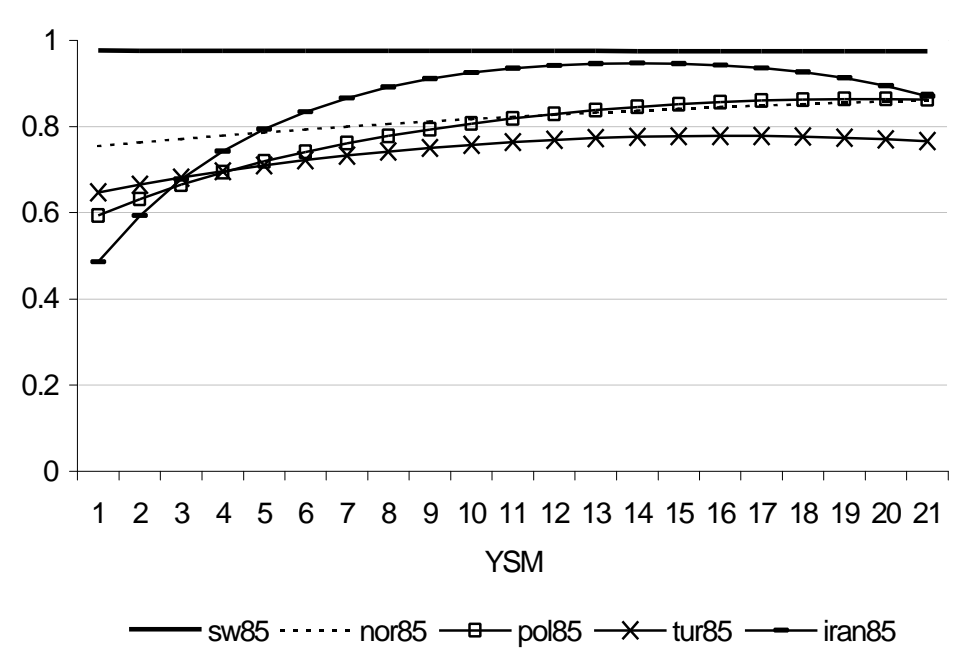

\section{Sweden 1995}

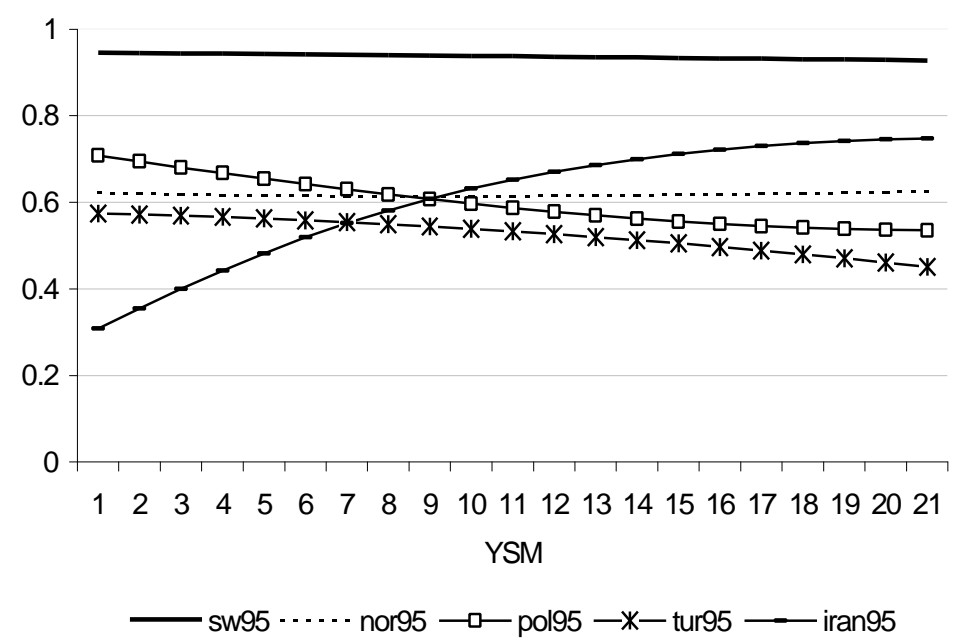


By 1995 this situation had changed considerably, with increased years in Sweden leading in general to decreased employment probabilities. The initial employment probabilities in 1995 were generally lower than in 1985, and these appear to decrease as time goes by. An example here could be the Turks. Based on the 1985 profile, it is seen that a 26 year old Turkish male should have a 65 percent chance of being employed during his first year in Sweden. Using the same profile, a 36 year old Turk (initial age (26) + ysm (10)) having lived in Sweden for 10 years should have a 76 percent probability of being employed. Moving the clock forward to 1995, we see that the initial employment probability for the 26 year old is now only 57 percent, while the 36 year old now only has a 54 percent chance of employment.

Looking at these graphs provides some understanding of the relative labor market positions of different nationalities, but is not quite as clear on the actual assimilation process. In order to make this process more visible, Figure 4 has been constructed from the same information as above, using a familiar difference-in-differences approach. Here we plot the changes in employment probabilities for the different nationalities between 1985 and 1995, net of the changes in employment probability of the natives. Denote the employment profile of an immigrant by EI and the similar age profile of a Dane by ED. The diagrams below then plot

$$
\left(E I_{1995}-E I_{1985}\right)-\left(E D_{1995}-E D_{1985}\right)
$$

Thus, the diagrams become quite simple to interpret - any positive values indicate an improvement in labor market position relative to natives, and negative values show deterioration in standing.

Figure 4 shows that Norwegians both in Denmark and Sweden experienced a decline in employment assimilation of between 5 and 20 percentage points. There is a penalty to be paid in terms of employment for being Norwegian during 1995 that did not exist in 1985, and this penalty increases with increased time in the country.

Turning our focus to the Poles, we can see a quite similar pattern forming in both Denmark and Sweden. In both Denmark and Sweden the Polish men improved their employment situation remarkably during the first years in the country, only to see this positive movement turn negative as years in the country increases. Note that a negatively sloping difference-in- 
differences 'profile' implies that the assimilation profiles have generally become more negatively sloped during the period. Thus, spending time in the destination country is not as beneficial - in terms of employment prospects - to the individual in 1995 as it was in 1985.

Figure 4 Relative changes in employment assimilation, 1985 - 1995.
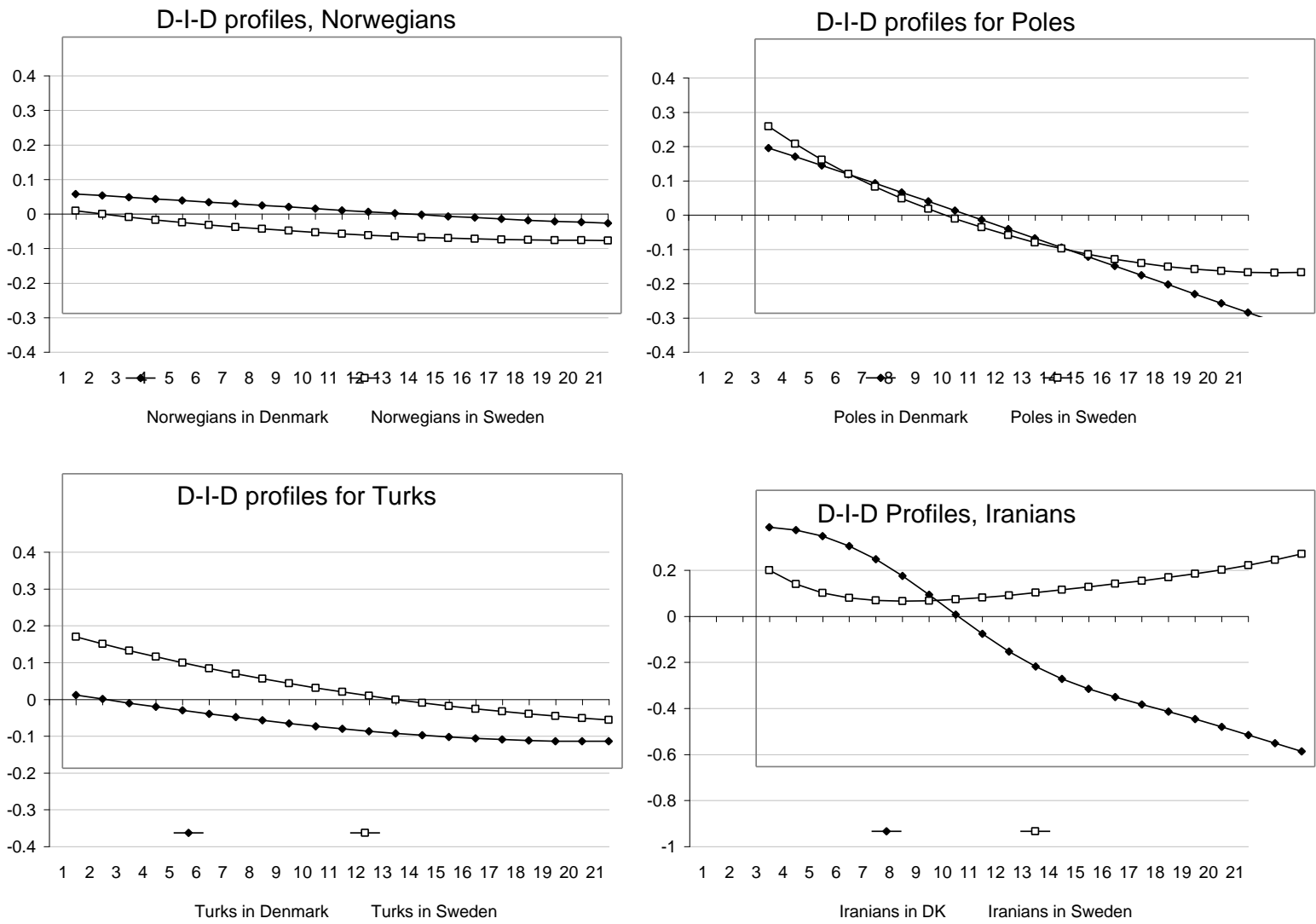

For Turks, there seems to be an across the board decline between 1985 and 1995 in employment prospects. The figure shows that Turkish employment assimilation declines for both Sweden and Denmark, with somewhat greater declines for those in Denmark. Turks in Sweden experienced relative declines of between 5 and 25 percentage points, while the Turks in Denmark saw drops of between 20 and approximately 34 percentage points. Note once again that not only the level, but also the slope of the assimilation profiles have changed during the period.

As with the Turks and Poles, the Iranians show worsening assimilation profiles in figure 4, with drops for both Swedish and Danish residents. The Swedish profile is positively sloped after 5 years in Sweden, implying improving assimilation profiles for Iranians, but the entire profile is still 8-28 percentage points below that of 1985, when adjusted for native performance. For 
Denmark, the initial situation of Iranians is virtually unchanged, but the assimilation profile has worsened dramatically. Note, however, that in 1985 very few Iranians had spent more than 5-10 years in Denmark (the average was only 2 years), hence the profiles shown in Figures 2 and 4 must be taken with some caution, especially the latter part of them.

The employment profiles displayed here show that there appears to be no movement towards increasing relative employment rates among immigrants from Norway, Poland, Turkey, or Iran. On the contrary, the chances of obtaining employment for these immigrants is actually smaller in 1995 than in 1985, a fact which is in line with our expectations. In addition, it is seen that the deterioration is increasing with the degree of cultural distance to Denmark and Sweden, in general.

As stated in the hypotheses, it is expected that the organizational change of the economy would lead to weakened immigrant prospects, and that is what seems to be occurring. In 1985, we see that the employment profiles for immigrants in Denmark and Sweden were generally increasing and concave, which implies that employment prospects became brighter as one accumulated time in the host country. This could be the result of increased information or networks facilitating job acquisition. In 1995, these concave profiles had either flattened or turned convex, which points to a decreasing importance of time in the host country.

That the results are so similar for both countries is somewhat surprising, since the economic circumstances have differed greatly. Sweden had an aggregate unemployment level in 1985 of about 3 percent, while Danish unemployment was closer to 9 percent. By 1995, Sweden and Denmark both had unemployment levels of 8 to 10 percent. In other words, the unemployment situation in Denmark was relatively unchanged from the earlier period, while it was dramatically higher in Sweden. If immigrant employment performance was merely a reflection of cyclical patterns, then the Danish case should have remained relatively unchanged, while the Swedish one should have shifted, at least if the immigrants were more adversely affected than the natives.

A look at the difference-in-differences profiles for employment, however, shows that immigrants in the two countries were affected similarly by the changes during the ten years under observation. All nationalities in both countries saw declining employment prospects, not only for recently arrived immigrants, but also for those who had been in the destination country 
for a prolonged time. This could be the case if there was a change in labor demand with increasing emphasis placed on country-specific characteristics. In this case, employers may well be employing statistical discrimination in their hiring processes. Given their understanding that language and cultural factors are of importance, employers could restrict their potential employee pool to those who are more likely to have these characteristics. This would explain the decrease in employment prospects for those immigrants who can be expected to have accumulated country-specific human capital through their time spent in the destination country. The consequence of organizational change in both countries is that the (negative) signal of being an immigrant - with a lower level of informal, country specific skills such as language and cultural understanding - suddenly dominates the (previously positive) signal of having spent some time in the destination country - thus acquiring these skills.

Now that a pattern of worsening employment possibilities has been charted, it is of interest to examine the income performance of these immigrants. In a previous version of this paper, we performed the analysis of employment probabilities and income jointly in a panel data sample selection model similar to that used by Husted et al. (2000a), but we found essentially, that all the change over time was in the employment probabilities. ${ }^{11}$ Hence, in order to maintain the focus, we have chosen to ignore the income aspects of the assimilation story.

11 This is likely a result of low wage dispersion in the Scandinavian countries and the effect of a strong centralized collective bargaining system. 


\section{Conclusions}

In this article, we have investigated the empirical implications of organizational change in the labor market for immigrants in Denmark and Sweden from four selected countries. We have used administrative register data for immigrants and natives for the period 1985-1995 to estimate panel data probit models for being employed.

Denmark and Sweden are similar in many ways, but they differ in one important way, namely the evolution of unemployment during the period of investigation. In addition, organizational changes are very widespread in both economies, when compared to other OECD countries.

Employment assimilation is the key to economic assimilation in both Sweden and Denmark. The relative paucity of low-wage service employment in both countries leads to the conclusion that entrance into employment should be a major step towards assimilation into the country in general. This entrance into gainful employment seems to be becoming increasingly difficult.

The reasons for this may well be the very same factors which are adding to the international competitiveness of industrialized economies. Recent decades have seen a change in organizational structure in almost all sectors. The old hierarchical system of industrial production dating back to Taylor and beyond has been slowly eroded. Increasing use of information technology has allowed for the chaining of production processes and the consolidation of control (Snower 1999). This changing organization has placed a premium upon interpersonal communicative skills, since interaction between workers, and between workers and management has become more common and intense. The ability to rapidly and efficiently communicate information has become essential to the smooth functioning of modern organizations.

Given this, immigrants can be expected to be more adversely affected by the change than natives, and this indeed appears to be the case. Evidence from both Denmark and Sweden shows that immigrants in 1995 had poorer employment prospects than they had in 1985 . The fact that the shifts in prospects evident in the difference-in-differences profiles were similar for immigrants in both Denmark and Sweden gives support for the argument that this is caused by organizational change rather than other macroeconomic factors. Had the changing employment 
patterns been the result of primarily cyclical factors, then we would expect the Danish data to show almost no differences between 1985 and 1995, since these two years had quite similar levels of aggregate unemployment and GNP growth. This was not the case, however, and the fact that Denmark showed a similar pattern as Sweden, which had quite a different economic experience, leads us to conclude that the shifting economic performance of immigrants is the result of structural shifts in labor demand. These shifts, as mentioned above, serve to strengthen natives' positions at the expense of immigrants.

\section{References}

Baker, M. \& D. Benjamin (1994) "The Performance of Immigrants in the Canadian Labor Market," Journal of Labor Economics 12 (3): 369-405.

Bevelander, P. (1995) Labor Force Participation of Immigrants in Sweden 1960-1990. Fil. Lic-dissertation, Dept. of Economic History, Lund, Sweden.

(1998) "Employment and Structural Change. Economic Integration of Immigrants in the Swedish and Malmoe Labor Market 1970-1990." Gorter C, Nykamp P, Poot J (ed) Urban Areas of Host Nations, Economic Aspects of Labor Market Absorption and Sectoral Impacts. Routledge, Amsterdam.

Bevelander, P. \& H. Nielsen (1999) 'Declining employment assimilation of immigrants in Sweden: Observed or unobserved characteristics?" CEPR Discussion Paper 2132.

Bevelander P., B. Carlsson \& M. Rojas M, (1997) I krusbärslandets storstäder, Invandrare i Stockholm, Göteborg och Malmö, SNS förlag, Kristianstad.

Blos M., P. Fischer \& T. Straubhaar (1997) The impact of migration policy on the labor market performance of migrants: a comparative case study, New community, 23(4).

Borjas, G. (1985) "Assimilation, Changes in Cohort Quality, and the Earnings of Immigrants," Journal of Labor Economics, vol. 3, no. 4.

(1987), "Self-Selection and the Earnings of Immigrants," The American Economic Review 77, no. 4, pp.53153.

(1989) "The Self-Employment Experience of Immigrants," Journal of Human Resources, vol. 21.

(1994) "Immigrant Skills and Ethnic Spillover", Journal of Population Economics, 7:2

(1995) “Assimilation and Changes in Cohort Quality Revisited: What Happened to Immigrant Earnings in the 1980s?" Journal of Labor Economics, vol. 13, no. 2.

Broomé, P., A.-K. Bäcklund, C. Lundh \& R. Ohlsson (1996) Varför sitter 'Brassen’ på bänken? Stockholm: SNS Förlag.

Chiswick, B., Y. Cohen \& T. Zach (1997) "The Labor Market Status of Immigrants: Effects of the Unemployment Rate at Arrival and Duration of Residence," Industrial and Labor Relations Review 50 (2): 289-303.

Chiswick, B. \& M. Hurst (1996) "The Employment, Unemployment, and Unemployment Compensation Benefits of Immigrants," Research in Employment Policy Vol.1. 
Chiswick, B. \& P. Miller (1995) "The Endogeneity between Language and Earnings: International Analyses," Journal of Labor Economics, vol. 13, no. 2.

(1999) “Language Skills and Earnings among Legalized Aliens," Journal of Population Economics, 12(1).

Dustmann, C. (1994) Speaking Fluency, Writing Fluency and Earnings of Migrants. Journal of Population Economics 7 (2): 133-156.

(1999) "Temporary Migration, Human Capital, and Language Fluency of Migrants," Scandinavian-Journal-ofEconomics 101(2).

Ekberg, J. (1983) Inkomsteffekter av invandring, Lund: Lund Economic Studies, no. 27.

(1990) Invandrarna på arbetsmarknaden, DS 1990:35. Stockholm: Almänna förlaget.

(1991) Vad Hände Sedan? En studie av utrikes födda på arbetsmarknaden (What Happened Next? A Study of Foreign Born in the Labor Market). Växjö, 1991.

Fry, R. (1997) "The Increase in Idleness of Immigrants Arrivals: The Role of Age at Arrival, Refugees, and Country of Origin," Quarterly Review of Economics and Finance 37: 209-228.

Goldin, C. \& L. Katz (1996) “The Origins of Technology-Skill Complementarity,” NBER Working Paper 5657.

Hummelgaard, H., L. Husted, A. Holm, M. Baadsgaard \& B. Olrik (1995), Ethnic Minorities - Integration and Mobility, (In Danish), AKF Forlaget, Copenhagen.

Husted, L., H. S. Nielsen, M. Rosholm, \& N. Smith (2000a), "Employment and Wage Assimilation of Male First Generation Immigrants in Denmark," International Journal of Manpower, forthcoming.

(2000b), "Hit Twice ? Danish Evidence on the Double-Negative Effect on the Earnings of Immigrant Women." Mimeo.

Kamali, M. (1997) "Distorted integration: clientization of immigrants in Sweden," Uppsala multiethnic papers 41, Uppsala.

Kee, P. (1994) "Native-Immigrant Employment Differentials in the Netherlands: The Role of Assimilation and Discrimination." International Review of Applied Economics 8 (2): 174-196.

McManus, W.S. (1985) "Labor Market Assimilation of Immigrants: The Importance of Language Skills," Contemporary Policy Issues, vol. III.

OECD (1999), "Employment Outlook, June 1999”, chapter 4 (titled 'New Enterprise Work Practices and their Labour Market Implications'). OECD, Paris.

Ohlsson, R. (1975) Invandrarna på Arbetsmarknaden (Immigrants in the Labor Market). Economic historical publications, Lund, Sweden.

Penninx, R., J. Schoorl \& C. van Praag (1993) The Impact of International Migration Receiving Countries: The Case of the Netherlands. NIDI CBGS Publications, Swets en Zeitlinger, Amsterdam.

Schmidt, C. (1994) The Economic Performance of Germany’s East Europeans Immigrants. Discussion Paper 94/9, Ludwig-Maxmilians University, München, Germany.

Scott, K. (1995) Migrants in the Labor Market. Employment Patterns and Income Development of Immigrants to Sweden 1970-1990. Fil. Lic-dissertation. Dept. of Economic History, Lund, Sweden. 
(1999) The Immigrant Experience: Changing Employment and Income Patterns in Sweden, 1970 - 1993, Lund: Lund University Press.

Shields, M. \& S. Wheatley Price (1998) The Earnings of First and Second Generation Immigrants in England: An Investigation Using the Quarterly Labor Force Survey.“ Applied Economics, 30, pp. 1157-1168.

Snower, D. (1999) “The Organizational Revolution and its Labor Market Implications," Keynote address to the EALE conference, September, 1999.

Wadensjö, E. (1973) Immigration och Samhällsekonomi (Immigration and Social Economy), Lund. 
Figure A1. The evolution of employment rates for natives and immigrants in Denmark and Sweden.

\section{Sweden}

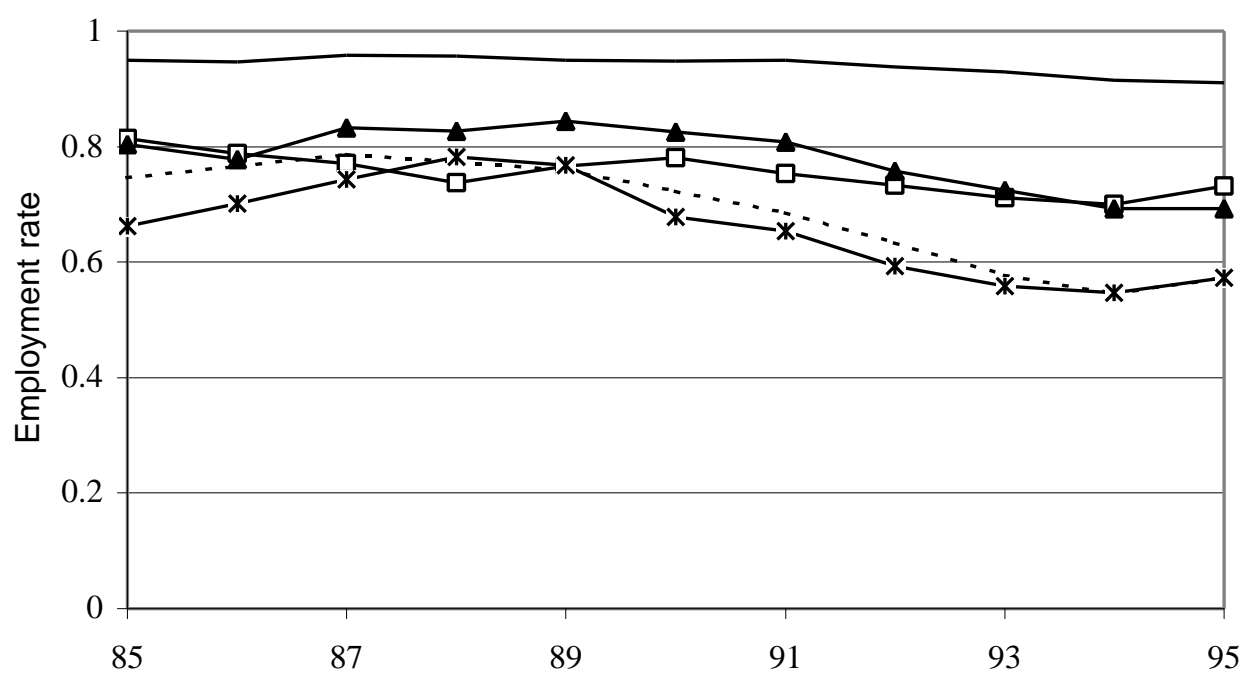

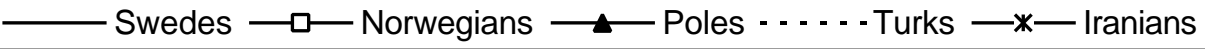

Denmark

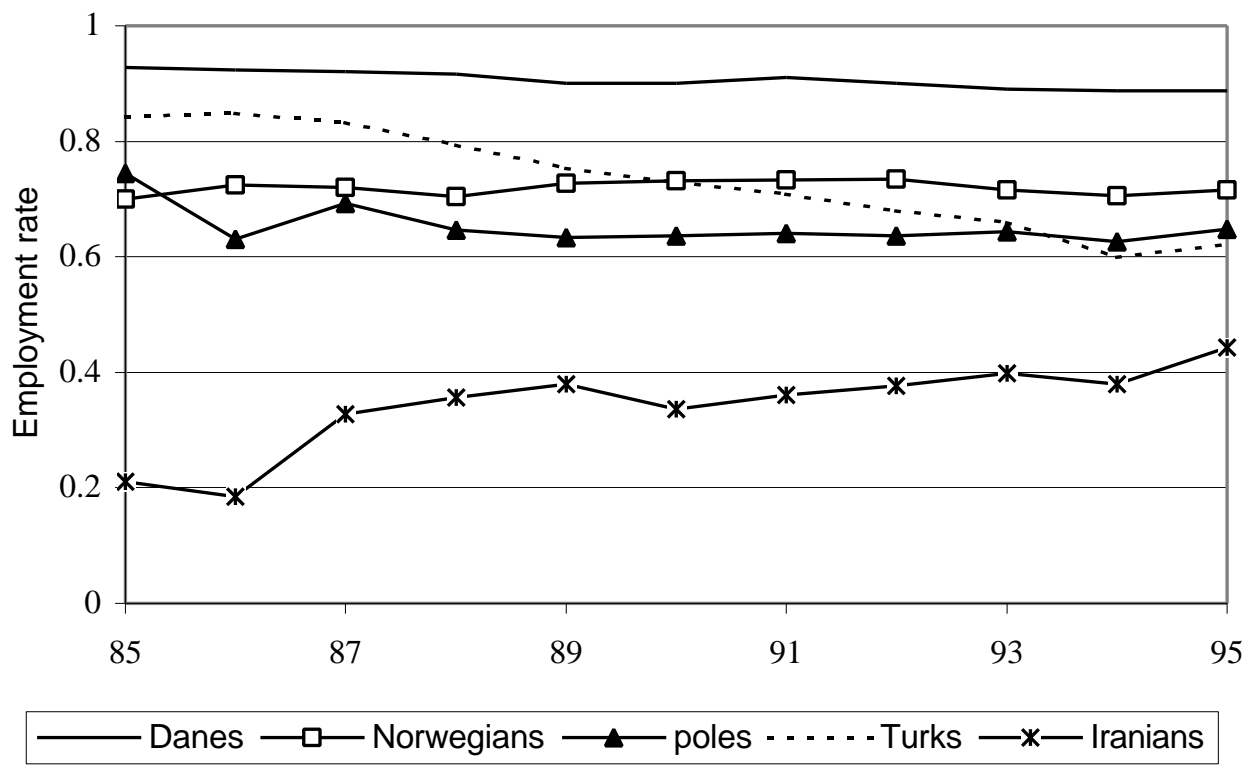


Table A1. Descriptive Statistics, Native and foreign-born population in Denmark, 1985 \& 1995.

\begin{tabular}{|c|c|c|c|c|c|c|c|c|c|c|}
\hline & \multicolumn{2}{|c|}{ Danes } & \multicolumn{2}{|c|}{ Norwegians } & \multicolumn{2}{|c|}{ Poles } & \multicolumn{2}{|c|}{ Turks } & \multicolumn{2}{|c|}{ Iranians } \\
\hline & Mean & Std. & Mean & Std. & Mean & Std. & Mean & Std. & Mean & Std. \\
\hline \multicolumn{11}{|l|}{1985} \\
\hline Educat., prim. & & & 0.086 & 0.280 & 0.077 & 0.267 & 0.228 & 0.419 & 0.018 & 0.132 \\
\hline Educat., second. & 0.457 & 0.498 & 0.023 & 0.151 & 0.049 & 0.216 & 0.006 & 0.079 & 0.013 & 0.114 \\
\hline Education, theo. 1 & 0.043 & 0.204 & 0.037 & 0.188 & 0.021 & 0.143 & 0.000 & 0.000 & 0.000 & 0.000 \\
\hline Education, theo. 2 & 0.070 & 0.255 & 0.045 & 0.207 & 0.044 & 0.206 & 0.000 & 0.000 & 0.009 & 0.093 \\
\hline Education, theo. 3 & 0.061 & 0.239 & 0.074 & 0.262 & 0.050 & 0.219 & 0.000 & 0.000 & 0.022 & 0.147 \\
\hline Marital status & 0.702 & 0.458 & 0.540 & 0.499 & 0.650 & 0.477 & 0.667 & 0.472 & 0.175 & 0.381 \\
\hline Naturalization & & & 0.102 & 0.303 & 0.569 & 0.496 & 0.007 & 0.085 & 0.053 & 0.224 \\
\hline Non-Metropolis & 0.883 & 0.321 & 0.334 & 0.472 & 0.409 & 0.492 & 0.239 & 0.427 & 0.237 & 0.426 \\
\hline No. Children & 0.713 & 0.946 & 0.581 & 0.905 & 0.695 & 0.883 & 1.362 & 1.374 & 0.303 & 0.745 \\
\hline YSM & & & 7.2 & 4.2 & 8.9 & 4.8 & 8.4 & 4.2 & 2.0 & 2.4 \\
\hline AAM & 38.4 & 10.5 & 30.2 & 8.9 & 28.3 & 9.2 & 21.8 & 7.9 & 25.1 & 6.0 \\
\hline \# observations & 136 & & 11 & & 67 & & 96 & & 22 & \\
\hline \multicolumn{11}{|l|}{1995} \\
\hline Educat., prim. & & & 0.066 & 0.248 & 0.098 & 0.297 & 0.243 & 0.429 & 0.077 & 0.266 \\
\hline Educat., second. & 0.478 & 0.500 & 0.032 & 0.177 & 0.041 & 0.198 & 0.005 & 0.069 & 0.050 & 0.218 \\
\hline Education, theo. 1 & 0.055 & 0.228 & 0.045 & 0.208 & 0.026 & 0.160 & 0.008 & 0.091 & 0.069 & 0.254 \\
\hline Education, theo. 2 & 0.091 & 0.288 & 0.055 & 0.228 & 0.037 & 0.189 & 0.009 & 0.094 & 0.077 & 0.266 \\
\hline Education, theo. 3 & 0.065 & 0.247 & 0.091 & 0.288 & 0.031 & 0.173 & 0.001 & 0.032 & 0.041 & 0.198 \\
\hline Marital status & 0.653 & 0.476 & 0.618 & 0.486 & 0.600 & 0.490 & 0.809 & 0.393 & 0.477 & 0.500 \\
\hline Naturalization & & & 0.152 & 0.359 & 0.487 & 0.500 & 0.112 & 0.315 & 0.371 & 0.483 \\
\hline Non-Metropolis & 0.892 & 0.311 & 0.274 & 0.446 & 0.277 & 0.448 & 0.190 & 0.393 & 0.249 & 0.433 \\
\hline No. Children & 0.584 & 0.932 & 0.653 & 0.996 & 0.641 & 0.886 & 1.617 & 1.355 & 0.563 & 0.921 \\
\hline YSM & & & 12.6 & 6.6 & 12.2 & 6.9 & 13.1 & 6.7 & 8.4 & 3.0 \\
\hline AAM & 39.6 & 10.9 & 27.8 & 9.2 & 26.3 & 9.0 & 18.8 & 8.2 & 26.7 & 7.2 \\
\hline Observations & 143 & & $13 \xi$ & & $14 \varepsilon$ & & 190 & & 168 & \\
\hline
\end{tabular}

Note: YSM is years since migration, AAM is age at migration. For Danes, AAM is the current age. 
Table A2. Foreign-born population in Sweden, 1985 \& 1995.

\begin{tabular}{|c|c|c|c|c|c|c|c|c|c|c|}
\hline & \multicolumn{2}{|c|}{ Swedes } & \multicolumn{2}{|c|}{ Norwegians } & \multicolumn{2}{|c|}{ Poles } & \multicolumn{2}{|c|}{ Turks } & \multicolumn{2}{|c|}{ Iranians } \\
\hline & Mean & Std. & Mean & Std. & Mean & Std. & Mean & Std. & Mean & Std. \\
\hline \multicolumn{11}{|l|}{1985} \\
\hline Educat., prim. & & & 0.014 & 0.119 & 0.003 & 0.058 & 0.003 & 0.053 & 0.000 & \\
\hline Educat., second. & 0.409 & 0.492 & 0.070 & 0.256 & 0.068 & 0.252 & 0.058 & 0.233 & 0.014 & 0.119 \\
\hline Education, theo. 1 & 0.077 & 0.267 & 0.016 & 0.123 & 0.013 & 0.115 & 0.003 & 0.053 & 0.018 & 0.132 \\
\hline Education, theo. 2 & 0.096 & 0.294 & 0.013 & 0.114 & 0.017 & 0.129 & 0.007 & 0.086 & 0.029 & 0.167 \\
\hline Education, theo. 3 & 0.008 & 0.089 & 0.001 & 0.035 & 0.001 & 0.029 & 0.002 & 0.043 & 0.007 & 0.084 \\
\hline Marital status & 0.504 & 0.500 & 0.484 & 0.500 & 0.561 & 0.497 & 0.752 & 0.432 & 0.562 & 0.497 \\
\hline Naturalization & & & 0.126 & 0.332 & 0.519 & 0.500 & 0.143 & 0.350 & 0.183 & 0.387 \\
\hline Non-Metropolis & 0.635 & 0.482 & 0.584 & 0.493 & 0.275 & 0.447 & 0.250 & 0.433 & 0.379 & 0.486 \\
\hline No. Children & 0.609 & 0.944 & 0.476 & 0.935 & 0.458 & 0.796 & 1.441 & 1.714 & 0.617 & 0.932 \\
\hline YSM & & & 11.4 & 11.4 & 10.2 & 8.3 & 8.6 & 6.6 & 6.3 & 6.0 \\
\hline AAM & 39.2 & 11.3 & 29.3 & 13.0 & 29.0 & 12.5 & 29.9 & 12.3 & 31.7 & 10.2 \\
\hline Observations & 12 & & 84 & & 11 & & 105 & & 56 & \\
\hline \multicolumn{11}{|l|}{1995} \\
\hline Educat., prim. & & & 0.054 & 0.226 & 0.067 & 0.249 & 0.078 & 0.269 & 0.012 & 0.111 \\
\hline Educat., second. & 0.510 & 0.500 & 0.160 & 0.366 & 0.176 & 0.381 & 0.126 & 0.332 & 0.075 & 0.264 \\
\hline Education, theo. 1 & 0.118 & 0.323 & 0.026 & 0.158 & 0.045 & 0.208 & 0.014 & 0.119 & 0.031 & 0.172 \\
\hline Education, theo. 2 & 0.110 & 0.313 & 0.023 & 0.150 & 0.030 & 0.171 & 0.006 & 0.080 & 0.055 & 0.229 \\
\hline Education, theo. 3 & 0.011 & 0.106 & 0.003 & 0.052 & 0.003 & 0.052 & 0.002 & 0.049 & 0.010 & 0.097 \\
\hline Marital status & 0.480 & 0.500 & 0.431 & 0.496 & 0.552 & 0.497 & 0.699 & 0.459 & 0.563 & 0.496 \\
\hline Naturalization & & & 0.185 & 0.389 & 0.621 & 0.485 & 0.533 & 0.499 & 0.513 & 0.500 \\
\hline Non-Metropolis & 0.643 & 0.479 & 0.650 & 0.477 & 0.363 & 0.481 & 0.377 & 0.485 & 0.529 & 0.499 \\
\hline No. Children & 0.625 & 1.044 & 0.446 & 0.903 & 0.520 & 0.889 & 1.266 & 1.533 & 0.754 & 1.121 \\
\hline YSM & & & 14.5 & 10.4 & 14.8 & 8.4 & 13.6 & 8.0 & 11.4 & 7.2 \\
\hline AAM & 40.8 & 10.6 & 26.4 & 13.5 & 24.6 & 12.5 & 26.7 & 12.8 & 30.5 & 12.3 \\
\hline Observations & \multicolumn{2}{|c|}{1152} & \multicolumn{2}{|c|}{740} & \multicolumn{2}{|c|}{1503} & 12 & & \multicolumn{2}{|c|}{1050} \\
\hline
\end{tabular}

Note: YSM is years since migration, AAM is age at migration. For Danes, AAM is the current age. 
Table A3. Random effect models for native men aged 20-59 years.

\begin{tabular}{|c|c|c|c|c|}
\hline \multirow[b]{2}{*}{ Parameters } & \multicolumn{2}{|c|}{ Danes } & \multicolumn{2}{|c|}{ Swedes } \\
\hline & Estimates & Std. dev. & Estimates & Std. dev. \\
\hline Constant 1 & 4.162 & 0.452 & 2.674 & 0.594 \\
\hline Constant 2 & 2.252 & 0.451 & -0.184 & 0.595 \\
\hline D86 & -0.295 & 0.140 & -0.095 & 0.191 \\
\hline D87 & -0.512 & 0.186 & 0.343 & 0.301 \\
\hline D88 & -0.824 & 0.247 & 0.352 & 0.339 \\
\hline D89 & -1.214 & 0.310 & 0.306 & 0.437 \\
\hline D90 & -1.472 & 0.375 & 0.094 & 0.514 \\
\hline D91 & -1.629 & 0.453 & 0.222 & 0.617 \\
\hline D92 & -1.926 & 0.521 & -0.019 & 0.728 \\
\hline D93 & -2.209 & 0.584 & -0.214 & 0.798 \\
\hline D94 & -2.436 & 0.663 & -0.389 & 0.895 \\
\hline D95 & -2.723 & 0.734 & -0.377 & 1.008 \\
\hline Marital status & 0.703 & 0.035 & 0.586 & 0.063 \\
\hline Non-Metropolis & -0.406 & 0.042 & -0.216 & 0.051 \\
\hline Education, secondary & 0.687 & 0.032 & 0.427 & 0.055 \\
\hline Education, theoretical 1 & 0.537 & 0.087 & 1.049 & 0.134 \\
\hline Education, theoretical $2+3$ & 1.025 & 0.050 & 0.308 & 0.093 \\
\hline Children /10 & 2.157 & 0.306 & 2.949 & 0.434 \\
\hline Age /100 & -11.197 & 2.629 & 0.093 & 3.579 \\
\hline Age, squared /10000 & 10.116 & 3.232 & -0.201 & 0.454 \\
\hline Age-trend /100 & 1.482 & 0.374 & -0.161 & 0.519 \\
\hline Age-trend, squared/10000 & -2.035 & 0.455 & 0.008 & 0.064 \\
\hline $\operatorname{Pr}(\mathrm{C} 1)$ & 0.744 & 0.014 & 0.907 & 0.008 \\
\hline $\operatorname{Pr}(\mathrm{C} 2)$ & 0.256 & 0.014 & 0.094 & 0.008 \\
\hline Mean log likelihood & -0.21 & & -0.12 & \\
\hline Observations & 154 & & 134 & \\
\hline
\end{tabular}


Table A4. Random effect models for Norwegian men aged 20-59 years.

\begin{tabular}{|c|c|c|c|c|}
\hline \multirow[b]{2}{*}{ Parameters } & \multicolumn{2}{|c|}{ Denmark } & \multicolumn{2}{|c|}{ Sweden } \\
\hline & Estimates & Std. dev. & Estimates & Std. dev. \\
\hline Constant 1 & 2.043 & 0.163 & -1.190 & 0.177 \\
\hline Constant 2 & -0.360 & 0.163 & 1.254 & 0.171 \\
\hline D86 & 0.112 & 0.099 & -0.152 & 0.138 \\
\hline D87 & 0.055 & 0.095 & -0.235 & 0.119 \\
\hline D88 & -0.081 & 0.101 & -0.473 & 0.114 \\
\hline D89 & -0.038 & 0.099 & -0.323 & 0.120 \\
\hline D90 & -0.058 & 0.106 & -0.261 & 0.118 \\
\hline D91 & -0.080 & 0.115 & -0.463 & 0.118 \\
\hline D92 & -0.072 & 0.125 & -0.586 & 0.128 \\
\hline D93 & -0.214 & 0.134 & -0.730 & 0.123 \\
\hline D94 & -0.228 & 0.149 & -0.852 & 0.133 \\
\hline D95 & -0.158 & 0.158 & -0.751 & 0.140 \\
\hline Marital status & 0.534 & 0.034 & 0.259 & 0.040 \\
\hline Naturalization & 0.483 & 0.042 & 0.084 & 0.055 \\
\hline Non-Metropolis & -0.316 & 0.029 & -0.004 & 0.037 \\
\hline Education, primary & -0.514 & 0.046 & -0.279 & 0.136 \\
\hline Education, secondary & 0.088 & 0.049 & 0.784 & 0.085 \\
\hline Education, theoretical 1 & 0.175 & 0.082 & 0.968 & 0.270 \\
\hline Education, theoretical $2+3$ & 0.371 & 0.064 & 1.166 & 0.291 \\
\hline Children /10 & 1.000 & 0.180 & 1.191 & 0.196 \\
\hline YSM /100 & 0.435 & 2.292 & 6.202 & 1.012 \\
\hline YSM, squared /10000 & 0.036 & 12.780 & -10.447 & 2.692 \\
\hline AAM /100 & -1.968 & 0.864 & 3.451 & 0.818 \\
\hline AAM, squared /10000 & -1.587 & 1.343 & -7.331 & 1.162 \\
\hline YSM-trend /100 & -0.072 & 0.301 & -0.534 & 0.143 \\
\hline YSM-trend, squared/10000 & -0.052 & 1.465 & 1.137 & 0.386 \\
\hline $\operatorname{Pr}(\mathrm{C} 1)$ & 0.676 & 0.011 & 0.287 & 0.013 \\
\hline $\operatorname{Pr}(\mathrm{C} 2)$ & 0.324 & 0.011 & 0.713 & 0.013 \\
\hline Mean log likelihood & -0.3 & & -0.35 & \\
\hline Observations & 14 & & 97 & \\
\hline
\end{tabular}

Note: YSM is years since migration, AAM is age at migration 
Table A5. Random effect models for Polish men aged 20-59 years.

\begin{tabular}{lcrrr}
\hline & \multicolumn{2}{c}{ Denmark } & \multicolumn{2}{c}{ Sweden } \\
Parameters & Estimates & Std. dev. & Estimates & Std. dev. \\
\hline Constant 1 & 0.950 & 0.162 & -1.539 & 0.108 \\
Constant 2 & -0.903 & 0.161 & 0.772 & 0.106 \\
D86 & -0.184 & 0.101 & -0.162 & 0.092 \\
D87 & 0.055 & 0.098 & 0.234 & 0.092 \\
D88 & -0.106 & 0.104 & 0.245 & 0.094 \\
D89 & -0.140 & 0.101 & 0.468 & 0.091 \\
D90 & -0.041 & 0.109 & 0.525 & 0.088 \\
D91 & 0.015 & 0.116 & 0.584 & 0.094 \\
D92 & 0.048 & 0.128 & 0.400 & 0.091 \\
D93 & 0.155 & 0.141 & 0.358 & 0.095 \\
D94 & 0.195 & 0.155 & 0.372 & 0.100 \\
D95 & 0.411 & 0.168 & 0.538 & 0.105 \\
Marital status & 0.384 & 0.029 & 0.161 & 0.030 \\
Naturalization & 0.222 & 0.036 & 0.284 & 0.032 \\
Non-Metropolis & -0.275 & 0.027 & 0.081 & 0.031 \\
Education, primary & -0.096 & 0.053 & -0.241 & 0.095 \\
Education, secondary & 0.308 & 0.046 & 0.832 & 0.061 \\
Education, theoretical 1 & 0.379 & 0.105 & 0.625 & 0.093 \\
Education, theoretical 2+3 & 0.769 & 0.066 & 0.347 & 0.105 \\
Children /10 & -0.226 & 0.154 & 1.671 & 0.164 \\
YSM /100 & 9.293 & 2.194 & 19.184 & 0.848 \\
YSM, squared /10000 & 0.324 & 12.110 & -51.122 & 2.479 \\
AAM /100 & -1.118 & 0.806 & 0.383 & 0.556 \\
AAM, squared /10000 & -1.078 & 1.327 & -2.122 & 0.914 \\
YSM-trend /100 & -0.787 & 0.293 & -2.421 & 0.115 \\
YSM-trend, squared/10000 & -1.302 & 1.406 & 6.295 & 0.308 \\
Pr(C1) & 0.634 & 0.014 & 0.275 & 0.011 \\
Pr(C2) & 0.367 & 0.014 & 0.725 & 0.011 \\
Mean log likelihood & -0.48223 & & -0.35809 & \\
Observations & 13291 & & 14986 & \\
\hline Note: YSM is years since & & &
\end{tabular}

Note: YSM is years since migration, AAM is age at migration 
Table A6. Random effect models for Turkish men aged 20-59 years.

\begin{tabular}{|c|c|c|c|c|}
\hline \multirow[b]{2}{*}{ Parameters } & \multicolumn{2}{|c|}{ Denmark } & \multicolumn{2}{|c|}{ Sweden } \\
\hline & Estimates & Std. dev. & Estimates & Std. dev. \\
\hline Constant 1 & 2.393 & 0.121 & -0.084 & 0.114 \\
\hline Constant 2 & 1.062 & 0.117 & 1.885 & 0.115 \\
\hline D86 & 0.121 & 0.080 & -0.051 & 0.088 \\
\hline D87 & 0.056 & 0.078 & 0.118 & 0.093 \\
\hline D88 & -0.168 & 0.080 & 0.110 & 0.093 \\
\hline D89 & -0.339 & 0.079 & 0.105 & 0.090 \\
\hline D90 & -0.344 & 0.085 & 0.020 & 0.092 \\
\hline D91 & -0.451 & 0.094 & -0.092 & 0.093 \\
\hline D92 & -0.617 & 0.100 & -0.242 & 0.091 \\
\hline D93 & -0.603 & 0.112 & -0.419 & 0.098 \\
\hline D94 & -0.754 & 0.121 & -0.489 & 0.104 \\
\hline D95 & -0.662 & 0.134 & -0.309 & 0.115 \\
\hline Marital status & 0.142 & 0.033 & 0.230 & 0.032 \\
\hline Naturalization & 0.077 & 0.053 & 0.259 & 0.030 \\
\hline Non-Metropolis & -0.133 & 0.033 & -0.242 & 0.033 \\
\hline Education, primary & 0.039 & 0.032 & -0.359 & 0.104 \\
\hline Education, secondary & 0.435 & 0.104 & 0.317 & 0.076 \\
\hline Education, theoretical 1 & 1.224 & 0.186 & 1.115 & 0.286 \\
\hline Education, theoretical $2+3$ & 0.372 & 0.165 & 0.754 & 0.238 \\
\hline Children /10 & -0.242 & 0.097 & 0.783 & 0.076 \\
\hline YSM /100 & -2.049 & 1.463 & 8.856 & 0.808 \\
\hline YSM, squared /10000 & -2.508 & 6.672 & -28.121 & 2.224 \\
\hline AAM /100 & 0.177 & 0.691 & 0.299 & 0.637 \\
\hline AAM, squared /10000 & -7.368 & 1.466 & -7.857 & 1.008 \\
\hline YSM-trend /100 & -0.190 & 0.219 & -0.888 & 0.150 \\
\hline YSM-trend, squared/10000 & 0.644 & 0.886 & 1.851 & 0.451 \\
\hline $\operatorname{Pr}(\mathrm{C} 1)$ & 0.457 & 0.018 & 0.422 & 0.014 \\
\hline $\operatorname{Pr}(\mathrm{C} 2)$ & 0.543 & 0.018 & 0.578 & 0.014 \\
\hline Mean log likelihood & -0.5 & & -0.43 & \\
\hline Observations & 16 & & 126 & \\
\hline
\end{tabular}

Note: YSM is years since migration, AAM is age at migration 
Table A7. Random effect models for Iranian men aged 20-59 years.

\begin{tabular}{|c|c|c|c|c|}
\hline \multirow[b]{2}{*}{ Parameters } & \multicolumn{2}{|c|}{ Denmark } & \multicolumn{2}{|c|}{ Sweden } \\
\hline & Estimates & Std. dev. & Estimates & Std. dev. \\
\hline Constant 1 & -0.448 & 0.258 & -2.005 & 0.156 \\
\hline Constant 2 & -1.842 & 0.259 & 0.166 & 0.158 \\
\hline D86 & 0.123 & 0.138 & -0.186 & 0.124 \\
\hline D87 & 0.492 & 0.132 & -0.032 & 0.118 \\
\hline D88 & 0.449 & 0.128 & 0.204 & 0.112 \\
\hline D89 & 0.392 & 0.133 & 0.167 & 0.108 \\
\hline D90 & 0.111 & 0.136 & 0.118 & 0.106 \\
\hline D91 & 0.050 & 0.145 & -0.062 & 0.112 \\
\hline D92 & 0.108 & 0.153 & -0.304 & 0.114 \\
\hline D93 & 0.142 & 0.170 & -0.473 & 0.120 \\
\hline D94 & 0.192 & 0.191 & -0.602 & 0.128 \\
\hline D95 & 0.478 & 0.211 & -0.594 & 0.141 \\
\hline Marital status & 0.175 & 0.031 & 0.129 & 0.038 \\
\hline Naturalization & 0.186 & 0.041 & 0.394 & 0.039 \\
\hline Non-Metropolis & -0.206 & 0.033 & -0.035 & 0.035 \\
\hline Education, primary & 0.088 & 0.078 & 0.275 & 0.347 \\
\hline Education, secondary & 0.363 & 0.041 & -0.111 & 0.128 \\
\hline Education, theoretical 1 & 0.256 & 0.075 & -0.391 & 0.128 \\
\hline Education, theoretical $2+3$ & 0.530 & 0.065 & 0.350 & 0.088 \\
\hline Children /10 & -0.346 & 0.196 & 1.290 & 0.176 \\
\hline YSM /100 & 34.754 & 4.782 & 42.965 & 1.890 \\
\hline YSM, squared /10000 & 1.226 & 33.914 & -166.701 & 8.794 \\
\hline AAM /100 & -0.726 & 1.538 & -0.634 & 0.757 \\
\hline AAM, squared /10000 & -4.320 & 2.469 & -2.143 & 1.102 \\
\hline YSM-trend /100 & -1.397 & 0.584 & -2.446 & 0.240 \\
\hline YSM-trend, squared/10000 & -8.711 & 3.686 & 11.708 & 1.009 \\
\hline $\operatorname{Pr}(\mathrm{C} 1)$ & 0.387 & 0.016 & 0.270 & 0.015 \\
\hline $\operatorname{Pr}(\mathrm{C} 2)$ & 0.613 & 0.016 & 0.730 & 0.015 \\
\hline Mean log likelihood & -0.53 & & -0.43 & \\
\hline Observations & 145 & & 90 & \\
\hline
\end{tabular}

Note: YSM is years since migration, AAM is age at migration 


\section{IZA Discussion Papers}

\section{No Author(s)}
171 C. Dustmann
F. Windmeijer
172
D. Card

173

174

175

176

O. Hübler

W. Meyer

177 B. R. Chiswick

G. Repetto

178 R. Euwals

M. Ward

179 E. Wasmer

P. Weil

180 T. K. Bauer

I. N. Gang

181 E. Wasmer

Y. Zenou

182 M. Fertig

C. M. Schmidt

183 M. Fertig

C. M. Schmidt

184 M. Corak

B. Gustafsson

T. Österberg

185 H. Bonin

K. F. Zimmermann
Titel

Area

Date

Wages and the Demand for Health - A Life Cycle

5

Analysis

Reforming the Financial Incentives of the Welfare

System

Timing, Togetherness and Time Windfalls

5

$7 / 00$

Does Money Illusion Matter? An Experimental Approach

Self-Employment and Earnings among HighSkilled Immigrants in the United States

Industrial Relations and the Wage Differentials

between Skilled and Unskilled Blue-Collar

Workers within Establishments: An Empirical

Analysis with Data of Manufacturing Firms

Immigrant Adjustment in Israel: Literacy and

Fluency in Hebrew and Earnings

The Renumeration of British Academics

5

$7 / 00$

The Macroeconomics of Labor and Credit Market Imperfections

Sibling Rivalry in Educational Attainment:

The German Case

Space, Search and Efficiency

$8 / 00$

$8 / 00$

Discretionary Measures of Active Labor Market

Policy: The German Employment Promotion Reform in Perspective

Aggregate-Level Migration Studies as a Tool for 1 Forecasting Future Migration Streams

$8 / 00$

Intergenerational Influences on the Receipt of

3

$8 / 00$

Unemployment Insurance in Canada and Sweden

The Post-Unification German Labor Market

4

$8 / 00$ 
A. S. Kalwij

The Myth of Worksharing

A. Zaidi

Is Unemployment Really Scarring? Effects of

The Determination of Wages and the Gender 
220 W. A. Cornelius

E. A. Marcelli

221

C. Grund

222 W.P.M. Vijverberg

223 M. Rosholm

M. Svarer

J. Schwarze

L. Modesto

J. P. Thomas

P. A. Puhani

227

L. Locher
G. Brunello

S. Comi

C. Lucifora
R. Coimbra
T. Lloyd-Braga
L. Modesto

230

L. Modesto

231

G. Saint-Paul

E. Bardasi

M. Francesconi

C. Dustmann

C. M. Schmidt
The Changing Profile of Mexican Migrants to the

Wages as Risk Compensation in Germany

On the Identification of Relative Wage Rigidity Cross-Section Data and Empirical Evidence for Poland in Transition

Immigration from the Eastern Block and the former Soviet Union to Israel: Who is coming when?

The College Wage Gap in 10 European

\section{Fluctuations} and Earnings: An Empirical Study for Portugal 

1969-95 the 1990s

244 S. M. Fuess, Jr. M. Millea

Pay and Productivity in a Corporatist Economy: 
250 T. J. Hatton

The Optimal Level and Composition of

Retirement Benefit Systems

Demographic and Economic Pressure on 